\title{
Abuse of Punishment in Transitional Justice And Its Damage to Construction Democratic Political - The Iraqi Experience after 2003 as a Model
}

\author{
BASMA KHALEEL NAMUQ M. A \\ Assistant Professor College of Political Science, University of Baghdad research field: political science: \\ international studies \\ College of Political Science, University of Baghdad Al - JADRIYA Complex, Baghdad, Iraq \\ Assistant Professor Dr. Mohamed Aziz Abdul-Hassan Al-BAYATI \\ College of Political Science, University of Baghdad research field: political science: international studies \\ College of Political Science, University of Baghdad Al - JADRIYA Complex, Baghdad, Iraq
}

\begin{abstract}
Objectives: The importance of the study stems from the fact that the region with all its countries, including Iraq, was and still lacks political stability, whether due to internal factors or external influences, or the conciliation of workers, and since transitional justice is an important idea, and essential in managing the stages of change, a solid democratic state that concerns everyone and cares, Everyone participates, from here, and through the centrality of the issue of change and the importance of the issue of transitional justice in it, and through the fact that the transitional experience in Iraq is a practical experience that took place early in the region, and in a pluralistic society that reflects the previous regime in which there are many features, and common to most of the prevailing political systems in the region This makes the study of his experience in this topic and the problems he encountered a suitable case for a useful study with an impact on more than one level.

The research paper aims to study the negative aspects of Iraq's experience in the field of transitional justice, and its transformation from a transitional justice case into a tool of factional and partisan revenge, whose procedures are marred by a lot of arbitrariness, which makes the topic useful for those who work to implement these programs in the future in order to avoid problems and mistakes .

Methods : The study adopts an analytical, inductive approach that relies on uncovering facts by starting from the details, then proceeds gradually to laws, general rules, and the college, where the Iraqi experience, its details, and the internal and external influences that accompanied it will be examined, down to the features and features And the facts of this experience, especially the negative aspects of it that affected the state of stability and construction in it, and this is particularly evident by analyzing the trends, paths, and problematic of transitional justice interventions in the current political transformations in Iraq after 2003, because understanding the course of the struggle for power and the influence between the components It will help us understand the dimensions of the competition for power and influence between these political blocs that represented the Iraqi opposition during the days of the political system under the rule of the (Baath Party) before its fall in 2003.

By perpetuating the phenomenon of competition and conflict between political blocs, including the perpetuation of two phenomena: The first is uncertainty about the possibility of renewed violence in the future.

The second is the intense competition over how to institutionalize the balance of power in Iraq after 2003.

Results: The failure of transitional justice in Iraq, and the failure to implement its real mechanisms that do not contradict human rights principles, was the reason for Iraq to reach its current stage, and the increase in impunity and injustice of persons who were not the cause of committing any human rights violations.

The results indicate that the last feature is indeed important because the deep partisan motives linked mainly to sectarianism, ethnicity, nationalism, and to a lesser extent regionalism, are the main determinants of the competition between the Iraqi political blocs that took over the rule of Iraq after 2003.

The reasonable explanation is that a sense of the narrow political and partisan gains of these Iraqi political blocs may compensate for the debts owed due to past violations and urge a preference for avoiding the pursuit of truth or punishment for fear that political gains may be threatened in some way.

Conclusions : Failure to resort to fair legal accountability causes new human rights violations, so the following question can be raised: Does ignoring legal accountability increase the number of perpetrators of violations, and help some of the perpetrators in the previous regime to get away from punishment, and wrong others? And that the negative engagement in transitional justice file, ignoring legal mechanisms, and to obey the wishes of the party, and lead to factional influence in the political process and thus stumble in the democratic transition?
\end{abstract}

Keywords: Democratic political Iraqi punishment transitional justice damage construction

DOI: $10.7176 / \mathrm{EJBM} / 13-6-03$

Publication date:March $31^{\text {st }} 2021$ 


\section{Introduction}

The problematic of the study and its questions : That failure to resort to fair legal accounting causes new violations of human rights, so can be asked the following question Does neglecting legal accountability increase the number of perpetrators of violations, and help some of the perpetrators in the former regime to escape punishment, and unfairness of others, and that the negative handling of the file of transitional justice, ignoring the legal mechanisms, and compliance with party and party desires lead to influence the political process and therefore faltering In the democratic transition?

The hypothesis of the study: The study is based on the hypothesis that "the failure of transitional justice in Iraq after 2003, and the failure to implement its real principles (which are not contrary to the principles of human rights), have led to the arrival of Iraq to its current stage, and the increasing cases of impunity and injustice of persons who were not the cause of committing Any violations of human rights

Research Methodology: The study is based on an analytical approach, based on the fact-finding, by starting from the details. It then proceeds gradually to the laws, general rules and the college. The components of the Iraqi experience, its details, and the internal and external influences that accompany it will be examined. , And the facts of this experiment, especially the negative aspects of them, which affected the state of stability, and construction The importance of the study and its objectives: The importance of the study stems from the fact that the region with all its countries, including Iraq, was and still lacks political stability, whether due to internal factors or external influences, or the conciliation of workers, and since transitional justice is an important idea, and essential in managing the stages of change, a solid democratic state that concerns everyone and cares, And everyone will participate, from here, and through the centrality of the issue of change and the importance of the issue of transitional justice in it, and through the fact that the transitional experience in Iraq is a practical experience that took place early in the region, and in a pluralistic society that reflects the previous regime in which there are many features, and is common to most of the prevailing political systems in the region. This makes the study of his experience in this topic and the problems he encountered a suitable case for a useful study with an impact on more than one level.

The research paper aims to study the negative aspects of Iraq's experience in the field of transitional justice, and its transformation from a transitional justice case into a tool of factional and partisan revenge, whose procedures are marred by a lot of arbitrariness, which makes the topic useful for those who work to implement these programs in the future in order to avoid problems and mistakes

The problematic of the study and its questions Failure to resort to fair legal accountability causes new human rights violations to be committed, so the following question may be raised Does ignoring legal accountability increase the number of perpetrators of violations, and helps some of the perpetrators in the previous regime to escape punishment, and injustice to others? In the democratic transition?

Study hypothesis The study starts from the hypothesis that ((that the failure of transitional justice in Iraq, and the failure to implement its real mechanisms (which do not contradict the principles of human rights) were the reason for Iraq to reach its current stage, and the increase in cases of impunity and injustice of persons who were not the cause of committing any rights violations. Human

The study adopts an analytical, inductive approach that relies on uncovering facts by starting from the details, and then proceeds gradually to laws, general rules, and the college, where the Iraqi experience, its details, and the internal and external influences that accompanied it will be examined down to the features and features And the facts of this experiment, especially its negative aspects, which affected the state of stability and construction in it. The study is divided into three sections, an introduction, and a conclusion, where the first section of the study deals with the conceptual and theoretical aspect of the topic as the basis, and the scale that will be adopted to evaluate and discuss the applications in the Iraqi experience that took place after the year 2003, and continued in the various stages of the experiment until after the war, and victory On ISIS

In the first section of the study, weaknesses and theoretical deficiencies in the concept of transitional justice will also be presented in order to allow for errors and breaches to achieve the principles of justice, and to take into account human rights aspects when applied. The second section of the study will focus on reviewing, discussing and analyzing the procedures In Iraq after the year 2003 and until 2014, when the ISIS crisis began, the fall of the city of Mosul and the start of the war against ISIS.

The third section of the study will be devoted to reviewing, discussing, and analyzing the applications of transitional justice after 2014 and with those involved in cooperation with ISIS in the liberated and occupied areas of Before ISIS

The theoretical and conceptual aspect: - Transitional justice

The name transitional justice is due to the political transformations that human rights activists wanted to include the violations that took place by the political systems without risking these transformations, and since these transformations were known as transition to democracy

Transitions to Democracy, to which justice was added, and he began to call it Justice Transitional Justice (1) Dr. Laila Nicolas Rahbani ( 2011), p. 97) . 
It is worth noting that the term transitional justice is one of the modern concepts at the national and international level, and it falls under the studies of human rights. Some also see it as one of the branches of international humanitarian law, and others see it within the jurisprudence of political science. Human.

First: - Defining Transitional Justice Language: Justice is against injustice, and what has been done by the souls is that it is righteous as justice, justice, moderation, and moderation, justice that modifies unjust from righteousness, and justice with the word of one, and this is a name for the plural, a man of justice who does justice to an unjust, and a woman of justice, and ideal justice and equal as justice and justice and your justice is equivalent to you.

)2 (Al-Fayrouz Abadi, Al-Qamoos Al-Muheet, ,( 1952), p.

Abi al-Hasan Ali bin Ismail bin Sayyidat al-Mursi, (2000), p. 11

It is said that there is justice for him in the case, for he is just, and so-and-so is among the people of the modification to open the signifier, i.e. from the people of justice, and a man of justice, i.e. consent, and convincing in testimony. Arabic, however, the most use of the meaning of justice is settled in that for the rights attached to the human being, so he used justice in ruling among people, and in saying to them, and in personal rights, and from here I found a correct link between moral law and justice, as they are linked and inseparable, even if they are completely differentiated The rule of justice is based on the nature of the accidents themselves, and these accidents are not hypothetical matters invented by the participants, but rather perceptual incidents. As for the specific origin of justice, it depends on what the person himself perceives, i.e. on the moral law, and the same is the case because the moral law is the obligation for a person to respect justice (3) Muhammad Ibn Abi Bakr Ibn Abd al-Qadir alRazi, (1981), p. 417. P. 231.

And the transition: the change from one state to another and the transition from one place to another, the transitional: a non-permanent place ((a transitional government)) a government that is paving it for a future stage, and it is said ((the transitional phase)) and ((4) Dr. Khalil Al-Jar, Modern Arabic Lexicon, (1973), p. 819)

Second: - Defining transitional justice as a term:

Dr. (Radwan Ziada) defined transitional justice ((it is a field of activity, or investigation, that focuses on societies that have a great legacy of human rights violations, genocide, or other forms of violations that include crimes against humanity, or civil war, in order to Building a more democratic society for a secure future

As for Dr. (Abdel-Hussein Shaban), he defined transitional justice as

The transition from an internal armed conflict to a state of peace, or the transition from authoritarian political rule to a state of democratic rule, or freedom from foreign occupation by restoring, or establishing local government, and all of these stages are usually accompanied by some necessary reform measures, and an endeavor to make reparations for victims of serious violations

Professor (Luay Abbas Ghalib) defined it as ((a philosophy and methodology, and its goal is to address a judge of grave violations, and to help people to move directly, peacefully, and non-violently to democracy)).

Therefore, transitional justice can be defined as ((a series of interconnected elements, aiming at transition) The reality of societies that have gone through periods in which they have been subjected to many violations to a democratic society by taking measures, judicial procedures that are fair and impartial, and other non-judicial measures represented in revealing the truth of violations, compensation for victims and reparation, reform of state institutions, and national reconciliation between groups of society, in addition to Preserving the memory of violations to prevent their recurrence in the future(5) Ahmed Reda, , (1960), p. 47.

Dr. Mustafa Ahmed Fouad, , (1986), p. 14.

Transitional justice cannot be achieved without the proper application of transitional justice approaches and mechanisms, which consist of the following issues(6) Khaled Nasr Al-Sayed and Nevin Mohamed( 2012), p.9.

They are judicial investigations with officials who have committed human rights violations, especially senior officials, and their prosecution, and it may take place at the local, regional and international levels, and it may be carried out by special bodies such as the Special Court for Sierra Leone, and the first criminal case was before the Nuremberg trial, which was conducted for the Nazis in Germany after the World War.

The second Criminal prosecutions of those responsible for human rights violations and other crimes are among the most important judicial measures to achieve the goals of transitional justice, whether those courts are national, international, or mixed(7) Khaled Nasr Al-Sayed and Nevin Mohamed,( 2012), p.9

-Truth Disclosure Committees

They are temporary, non-judicial bodies that often operate for a year or two, are officially recognized, delegated by the state, derive their powers from them, and sometimes from the armed opposition, in addition to the state, or stipulated in a peace agreement, enjoying a degree of legal independence Usually arises in the midst of the transformation process, and the transition focuses its attention on the past, investigating certain patterns of violations committed over a period of time around one particular event that necessitates its work by submitting a final report that includes its conclusions and recommendations, and focuses in its work on human rights violations and humanitarian standards (8) Counselor Adel Majed (2013, p. 14(( . 
Compensation and compensation for damage- :

One of the most important pillars of the concept of transitional justice is compensation for victims, and reparation for damages incurred by them. Compensation and reparation programs provide material compensation (financial compensation, financial incentives, and free services) or symbolic (formal apology for those affected by past violations. (

-Institutional reform- :

It is manifested at the level of general reforms that touch the administrative and financial aspect in various state institutions, as well as reforms related to specific institutions

-National Reconciliation- :

It means efforts aimed at establishing peace and national confidence among old opponents in the context of justice and accountability. True reconciliation depends on putting an unambiguous end to the threat of further violence and is closely related to transitional justice, and that reconciliation is one of the components of the transitional justice system. In itself, it is an important mechanism, as it is well established that national reconciliation is one of the most important vocabulary of any political settlement, and failure to achieve it may fail this settlement as a whole(9) Khaled Nasr Al-Sayed and Nevin Mohamed ( 2012), p.9. .

-Save memory- :

Memory revival is any event, event, or environment that functions as a mechanism for memory. Memory revival can take place either formally (such as erecting a memorial) or informally (a mural in a local community) and people seek to revive the memory of past events for many reasons, including desire. In evoking the memory of the victims, or identifying them, and working to heal the rupture and pain of an internal accident on the one hand, as well as working at the same time to share the memory, and grief with other members of the community, and to stand by the victims of the victims, and strengthen support, and fraternity with them in the face of pain, the state A duty to commemorate her victims with the powers and powers she possesses

Transitional justice procedures in Iraq from 2003-2014.

The process of democratization in Iraq and the transitional justice measures that emerged in its midst came as a result of the United States 'occupation of Iraq in 2003 and its overthrow of the former Ba'athist regime, and not through the influence of a mass movement supported by political forces, or through a compromising agreement between the existing regime and the forces of change, as it is.

In most of the experiences of societies that have lived through democratic transformation, where the opposition political forces usually have a role in changing the existing system, and they have the initiative to hold the reins of the democratic transformation process, and thus control transitional justice procedures according to an integrated plan, and this did not happen in Iraq, where they assumed power The American occupation (the Coalition Provisional Authority) alone played this role in light of an international public opinion rejecting the occupation, and a regional stance that is apprehensive and hostile to thwart its objectives, and the apparent absence of an Iraqi political class that has contact, and an effective influence on the course of events, because the dictatorial regime, with its repressive, cruel policy towards any A form of opposition, and the dispatch of society by means of seduction and coercion, did not allow the emergence of any political class that would be the alternative in the event of its fall. And it has the ability to determine the level of pace of the required course when taking transitional justice measures without causing any structural disruption to the nature of the existing societal harmony $(10)$ Counselor Adel Majed, (2013, p. 14 .

Iraq needed an integrated plan for democratic transition to bypass the vows of authoritarianism, discrimination, violence and aggression by adopting transitional justice mechanisms that respond to the priorities of the Iraqi people, including truth-telling, accountability and prosecution of perpetrators of human rights violations, compensation for victims and their families, and institutional reforms that lay the right foundations. For a comprehensive national reconciliation so that these violations are not repeated again, and the occupying power had to seek the assistance of the United Nations and international human rights organizations that have great experience in contributing to the implementation of transitional justice measures instead of the policy of unilateralism, and not taking into account the nature of Iraqi society

Among the most prominent transitional justice measures in Iraq are as follows: -

-De-Baathification procedures:

A- Order No. sought to eradicate the Baath Party and eliminate it by excluding its leaders from centers of power and responsibility in Iraqi society, and the matter required the exclusion of two categories of individuals from public administration positions as follows- :

First: - All individuals holding the first four ranks (member of the regional leadership, member of the branch, member of the division, and member of the division) are in the membership of the Baath Party, as they are considered senior members of the party.

Second: - All individuals from the three upper administrative classes (the General Manager and above) who joined 
the party membership at any level.

The order also prohibited the display of pictures of Saddam and other senior leaders, sought to initiate criminal investigations into the alleged crimes, and authorized the offering of rewards to those who provide information leading to their arrest. Exclusions were based exclusively on membership and rank in the party, and it assumed that these ranks represent the elite in the party. And that its imitators inevitably committed gross violations against human rights, and there was a similar rationale behind the dismissal of senior managers, according to which it is impossible for anyone at the level of the director general or higher to assume his position without personal participation in the party's crimes(11) Ahmed Shawki Banyoub, (2013, p. 131.(( .

The de-Baathification program is taken from many defects, and the first serious concern is that it was built on assumptions of guilt, not innocence, and generalized guilt at the community level, and this assumption led to poisoning the de-Baathification process, and the policies associated with it over the following years, and the second aspect is that the text of the matter was not taken into account. The necessity of preserving the functioning of the civil service, as it caused a major disruption in the work of the ministries of education and finance, as experienced workers were excluded from their jobs.

B - The order (2) sought for the CPA to dissolve the military, security and other organizations, as the matter was resolved by the Iraqi armed forces, security services, party militias, and other organizations that were famous for their roles in managing party affairs or for which the assets of the state could have been provided to the party Fundamental opportunities for him to return to power, and these organizations included the intelligence service, the Ministry of Defense, the army, the Navy, the Air Force, the Olympic Committee, and others, and all military ranks and titles were canceled, and the recruits and employees were dismissed as of April 16, 2003, and everyone received money in exchange for termination of service The pensions of workers continued, except for senior party members, including the members mentioned in Order No. (1), in addition to those with the rank of colonel and above.

The Interim Iraqi Governing Council, established by the US occupation authority, was established on August 18, 2003 (the Supreme National Commission for De-Baathification), and it is the entity that led de-Baathification initiatives over the following years. By September 1, 2003, Ahmad Chalabi was appointed head of the commission, and Mithal al-Alusi, his Sunni colleague. (12) Counselor Adel Majed, 2013), p. 14 .(

The Supreme National Authority for De-Baathification made a fundamental change in the framework of deBaathification, and although it targeted the same party, and the same administrative ranks that the CPA targeted, the Commission greatly expanded the scope of de-Baathification, prohibiting certain categories of individuals Holding high positions in the new state bureaucracy, politics, civic institutions, or means

These groups included members of the party at the level of party members, those who occupy a position in the civil service, or the equivalent at the level of the position of director general or higher, and members of (repressive institutions), known for their participation in the plunder of national wealth, the practice of repression, or the commission of Other crimes, the last three groups were not part of de-Baathification in the past, and thus the commission gave itself enormous new, unspecified powers that affect political participation, employment in the civil service and social status, and the economic well-being of thousands of Iraqis(13) Dr. Wahid Ferchichi 2015), p. 79 , .

-The High Iraqi Criminal Court 2005-2006: -

The court was set up to investigate and prosecute persons alleged to have committed crimes against humanity, war crimes, or genocide during Saddam Hussein's rule.

-The creation of the Supreme National Authority for Accountability and Justice- :

A new body was established (the Supreme National Commission for Accountability and Justice), and the Commission's law was issued in 2008 as it contained some improvements. It kept many restrictions from the previous law of the De-Ba'athification Commission, and the most important changes included:

A. A simpler, clearer basis for de-Baathification efforts, including more explicit requirements.

B- Allowing most members at the division level to return to government service, and those who held a high-level government position, or those who were employed in key institutions such as the Presidency Council, the Prime Minister's Council, the Supreme Judicial Council, and the Ministries of Foreign Affairs and Defense were not allowed to return.

C- Granting most of the demobilized individuals (members at the division and division levels) eligibility to receive pensions.

D. To take more hostile positions against employees of the intelligence agencies during the Ba'ath era who were to be discharged from government service regardless of whether they were members of the party.

E. Establish a stronger link with the criminal investigation effort.

F- Establishing seven new commissions to act as new leadership in the authority. 
G. Creation of an independent judicial appeals department, linked to the Iraqi Court of Cassation.

Judge Rahim Hassan Al-Aqili makes a set of notes on the De-Baathification Law and the ban on the Baath Party of 2015, as follows: (14)Dr. Salah Abdel-Rahman Al-Hadithi, The Role of the United Nations in the Work of Truth and Reconciliation Commissions, Al-Huqooq, 2008, p. 242.)((

-Expanding the framework of exclusion and ablation:

Law No. 10 of 2008 differentiates between members of the Ba'ath Party who are employees, so Article 6 Fifth of the current law of the proposed 2015 permits those who were in the rank of a member of a division without returning to their jobs, and their continuation therein, with the exception of everyone who holds special ranks only, and prohibiting members of the Baath Party from assuming positions of special ranks (Director General and above, and directors of administrative units), according to Article 6 / Seven, with two conditions: a. He must be a member or above in the Baath Party.

As for the current bill, it expanded the exclusion and the ban from several directions

The draft law expanded the framework of those included, in addition to members of the Baath Party and above, whoever worked in the category of political guidance, regardless of his party level, even if he was not a Baathist in origin (15) Basaer Ali Muhammad Al-Bayati , ,(2005), p. 278, .

.Expanding the framework of the covered persons:

The law stipulates that it is forbidden to assume the special ranks of the member, and that he has enriched himself at the expense of public money, while the draft law raised this condition, and thus it becomes covered by all members and everyone who worked for political guidance regardless of whether they influenced the public money account or not.

-Expansion of prohibited jobs:

The current law prohibits members from assuming special ranks (director general and above and directors of administrative units), and here it does not include membership in representative councils, while the proposed draft adds to the positions that are prohibited from membership in the House of Representatives, the Federation Council, or the provincial council

.Opening the doors of turning manipulation- :

The only recourse for those who are excluded by the ablation procedures is to appeal for cassation before the Cassation Commission with jurisdiction over accountability and justice in the Court of Cassation.

A-The current law allows those who were removed by the commission to appeal for cassation before a discriminatory panel of seven judges nominated by (the Supreme Judicial Council) and approved by the House of Representatives, however, the draft law made the nomination for (the President of the Supreme Judicial Council) instead of the Supreme Judicial Council under Article 10 / First. The nomination of the two cassation courts in the hands of one person instead of the Judicial Council made many question marks.

B - The current law states that the decision of the judicial body of cassation is categorical, and is made in accordance with Article (17) thereof, and therefore it cannot be tampered with in any way. As for the current draft law, it opened an appeal against the decision of that body which is to correct the discriminatory decision before the Federal Court of Cassation according to Article (10 / fourth), which is in the way of turning around the decisions of the judicial court of cassation and the mechanisms of its work, especially as it made the correction before the Court of Cassation and not before the Judicial Court itself, which is very strange, and contrary to the rules of appeal to correct the cassation decision( 16)Rahim Hassan Al-Aqili, 2015, www.alirqnews.com

Confiscating freedoms by criminalizing and opening the gates of political liquidation

The draft law adopted the criminalization of several extremely dangerous personal acts, as follows:

A- The law criminalizes acts that confiscate freedom of expression and the media, while it punishes with imprisonment between (5-10) years for those who promote the ideas of the Baath Party, or its opinions by any means, so what is the meaning of (promoted) ?? the language of (promoting something) means making it widespread. The news: he spread it, and promoted his words: his adornment, and the promotion of his speech made him vague and did not know his truth, then what is the meaning of ideas, and opinions of the Baath Party that he criminalizes who promoted ?? Arab unity is one of the ideas of the Baath Party, freedom is one of its ideas, and the same is socialism, so does he criminalize those who promote it ?? and training then Training is a slogan for the Baath Party, so does it incriminate those who advocate it, because this punitive text is one of the most dangerous and most confiscating freedoms of opinion, expression, and media, and it is a tool to liquidate anyone who disagrees, opposes, or is not wanted for any reason, and any person under it can be criminalized.

B - The law criminalizes anyone who contributes or helps through the media to spread the ideas and opinions of the Baath Party, and is punishable by imprisonment between (3-5) years. This text completely confiscates the freedom of media, publishing, and printing, and includes even those who publish ideas, or Opinions of the Baath Party for historical or academic purposes. If a researcher or historian writes or documents Baath Party literature in 
a book, then it is criminal according to this text ( 17. Rahim Hassan Al-Aqili, more exclusion and oppression in the Accountability and Justice Bill 2015, www.alirqnews.com ))

C - The draft law prohibited actions disconnected from the Baath Party, which are- :

First: Adopting or adopting racism, atonement, sectarian cleansing, inciting it, glorifying it, introducing it, or justifying it.

Second: Forcing a citizen to leave his place of residence for sectarian, religious, or national reasons.

Third: An allegation of discrimination, and a judicial proof of its invalidity, which are broad, unspecified texts that contradict the rules for determining crimes and penalties, and are a tool for confiscating freedoms, liquidating political opponents, and confiscating the freedoms of expression, the media, and publishing, as well as criminalizing acts that make the public employee in a dangerous situation When dealing with the rights of citizens, if an employee tries to deprive a citizen of a certain right, and then another comes and finds it worthy, then would the first person incriminate just because of his diligence?

Fourth: - The punitive texts mentioned in the draft law use general and non-specific terms, and they pose a threat to freedoms, basic rights, and human rights in Iraq(18) Miranda Saysons and Abdul Razzaq Al-Saadi, , 2013), p. 2

Transitional justice measures in Iraq after 2014

The armed forces of the Iraqi government and the Kurdistan Regional Government of Iraq, with the support of various international partners, including the United States of America and Iran, nearly ended their military campaign against the Islamic State (also known as ISIS) in Iraq. During this campaign, Iraqi government forces and the Iraqi Kurdistan Region forces detained thousands of fighters. And the elements suspected of belonging to ISIS, including hundreds of children. The judicial authorities of the Iraqi government and the regional government rely on anti-terrorism courts to expedite the trial of all ISIS suspects on charges under anti-terrorism laws, and the charges are often limited to belonging to the organization without any distinction. In terms of the degree of seriousness of the charge and without any efforts to give priority to the most serious crimes, a judicial source in Nineveh indicated that the courts began trials against 5,500 people suspected of belonging to ISIS, and issued judgments against at least 200 of them between February and late August 2017

))Human Rights Watch)) organization has indicated a set of dangerous indicators regarding the safety of the procedures adopted by the security forces, the Iraqi military forces, and the forces of the Iraqi Kurdistan region to sort out people leaving areas under the control of ISIS, and the organization has expressed its concern that the information approved to convict people The ambiguity of the procedures adopted for identifying ISIS suspects, which are based on wanted lists, or accusations issued by local residents without any additional evidence that may lead to wrong identification of persons, and to the detention of children and men who are not, or not.

They belong to ISIS, and the organization also affirms that people who are wrongly identified during the security audit process as being suspected of belonging to ISIS may spend months in mass, arbitrary detention during the period of the judicial investigation (17). Dr. Wahid Ferchichi and others, 2015), p. 79, .

The organization's observations indicate the procedures of the security authorities towards the file of the prosecution of those accused of having ties to ISIS as follows:

-Conditions of detention:

Conditions of detention and interrogations are also not without problems, as the organization found that the Iraqi authorities are detaining ISIS suspects in overcrowded places, and sometimes in inhumane conditions in which, for example, children are not separated from adult detainees, and systematically violate the safety procedures stipulated by the rights of suspects, including violations of due process..

- (20) Ahmed Shawki Banyoub, 2013, p. 131,

Ignoring the guarantees guaranteed in Iraqi law to bring the detainee to a judge within 24 hours, to contact a lawyer throughout the interrogation period, to inform families about the detention of their relatives, and to allow them to communicate with them, in addition to that many detainees claimed that the authorities tortured them to force them to confess to belonging to ISIS, and when officials were asked About these allegations, Iraqis answered that they had investigated them without providing any evidence for that.

-Trials- :

ISIS's actions are a serious security threat to the Iraqi state, as the organization has launched a wide range of attacks, including attacks against civilians, and has committed other criminal acts in all parts of Iraq. The organization says that the Iraqi authorities and the regional authorities have the right to conduct trials for these crimes to ensure the safety of citizens, and to achieve Justice for the victims, but the organization found a number of deficiencies in the trials of ISIS fighters and its affiliates (19 Basaer Ali Muhammad al-Bayati ,2005), p. 278, .

-Absence of a National Strategy:

The organization indicates that there is no national strategy for ISIS trials, and that the charges against suspected 
ISIS members do not include a wide range of crimes committed by ISIS, and judges from Iraq said that the antiterrorism courts in Iraq are working, but when asked about the general plan for trying ISIS crimes The judges told the organization that there is no national plan to coordinate these trials, or to give priority to the prosecution of those involved in the most serious crimes, instead the Iraqi authorities apparently rely on trying ISIS suspects under their respective anti-terror laws on charges of belonging to the organization without any discrimination, and without Any priority in terms of the seriousness of the crimes accused of committing it (20. Dr. Salah AbdelRahman Al-Hadithi, , 2008, p. 242.

-Reliance on anti-terrorism laws- :

The anti-terror laws adopted by the Iraqi government and the regional government have allowed judges to bring charges against a wide range of people, some of whom are not involved in specific acts of violence, but are seen as providing aid to ISIS, such as doctors who worked in ISIS-controlled hospitals, and cooks who They prepared food for fighters, and anti-terrorism laws stipulate harsh sentences even for mere affiliation with ISIS, which is life imprisonment, or death. Suspects of ISIS affiliation are accused of violating anti-terrorism laws, and no other charges under the penal code are often easier to prove. In these cases only to prove their involvement in specific criminal acts, which is a challenge considering that these crimes took place in the midst of the chaos of war, but relying on anti-terrorism laws raises problems, because it does not give priority to punishing the most serious crimes committed under the organization( 21) Rahim Hassan Al-Aqili, 2015 www.alirqnews.com

- Judicial record numbers and victim participation:

Prosecuting people by relying solely on anti-terrorism laws also raises problems, because this does not help in preparing a judicial record of the various crimes that were committed against countless Iraqi citizens, and gathering evidence related to them, as well as witnesses, and victims. Although the victims are still demanding justice, Iraqi trials usually The participation of victims, witnesses, and the authorities did not make any effort to guarantee participation

Victims in trials are either in attendance only, or as witnesses, or to present their accounts, or ask questions to the suspects. Instead, it seems that the authorities have focused only on providing victims with compensation, as for crimes against Yazidis, a specialized committee has been formed to scrutinize and even in these limited initiatives they did not Little contact with people is happening.

Some victims' representatives stated that they were not aware of the compensation plan. The authorities in Baghdad told the international organization that they had established a judicial body charged with investigating crimes against the Yazidis in order to prosecute the crimes committed against this sect. Victims, and criminal lawsuits were collected. Leaders of the Yazidi community said that they had never contacted this body.

-Child trial- :

Detaining children suspected of belonging to ISIS, and trying them may violate Iraq's human rights obligations related to the treatment of children, which stipulate that the best interests of the child be taken into account, resorting to detention as a last resort, giving priority to rehabilitation, and considering alternatives to detention ( 22 . Imperfect Justice: Accountability for ISIS Crimes in Iraq (2017), p. 1)

Conclusion

After completing this modest study, I came to the following conclusions- :

-Transitional justice is considered recent in its application in Iraq after the fall of the previous regime in 2003 to redress the victims, prosecute those involved in crimes that affect human rights, move to a new stage of construction, and rebuild after years of abuse, and harm the victims physically, psychologically, and morally.

-Among the observations that are taken on the implementation of the pillars of transitional justice the length of the work of the De-Baathification Commission, or the Accountability and Justice Commission that identified international organizations, including the International Center for Transitional Justice, such bodies have worked for a period not exceeding two years, while the work of the Commission since 2008 until now is still unjustly And not converting the file of accountability and justice into a judicial file to get rid of cases of abuse, and converting the file into a political file with operational effects, which makes it imperative to transfer this file to the judiciary to give its decisive word in it, and to close this file permanently, and to go towards the process of building the Iraqi human being, and rehabilitating him, whether he is free Or a victim.

.The need to pay attention to transitional justice procedures after 2014 in terms of codifying them, resolving cases, and removing those accused of belonging to ISIS in the absence of judicial evidence against them.

Recommendations- :

-Abolishing the Accountability and Justice Commission, and converting the ablation file into a judicial file, as it is no longer needed in the transitional justice file after 2003.

-Paying attention to studying the requests of those affected by the decisions of the Accountability and Justice Commission to bring them back to service, as long as no judicial complaint has been proven against them and their 
hands are not stained with blood.

Resolving the investigative cases in the file of the accused after the liberation of Mosul, in the absence of a complaint against them, and not convicted of final judicial decisions.

Proposals to develop transitional justice mechanisms in the future in light of the Iraqi experience- :

The necessity of redressing the oppressed and those affected by the decisions of the Accountability and Justice Commission after their re-evaluation, not on the basis of their affiliation with the party or their job service in previous departments, but according to their previous work, and the judicial complaints against them, if any .

The necessity of removing the judiciary from political influences

\section{References}

(1). Dr. Laila Nicolas Rahbani (2011) International intervention is understood in a phase of change, Beirut, AlHalabi Human Rights Publications, p. 97,

(2). Dr. Ayad Yunus Muhammad Al-Skali and Dr. Amer Hadi Abdullah Al-Jubouri,(2016) Transitional Justice: A Study Legal, College of Law and Political Science Journal, Issue 5, , p. 230

(3) Ali Bin Hadi and others,(1980) The New Dictionary for Students, ed. 2, Tunisia, Tunisian Distribution Company, p. 108

(4) Al-Fayrouz Abadi, Al-Qamoos Al-Muheet , ( 1952) Part 2 (Egypt, Al-Halabi Press, p. 373

(5) Abi Al-Hassan Ali bin Ismail bin Sayyidat Al-Morsi,(2000) The Great Arbitrator and the Ocean, Volume Two, Beirut, Dar Al-Kutub Al-'Almiyyah, p.11

(6) Muhammad Ibn Abi Bakr Ibn Abd al-Qadir al-Razi, Mukhtar As-Sahih, ( 1981) Beirut, Dar Al-Kitaab AlArabi p. 417

(7) Ahmad Reda,( 1960) The Dictionary of Language, Volume 4 Beirut, Dar Al Hayat Library, p. 47

(8) Dr. Mustafa Ahmed Fouad,(1986) The Concept of the Denial of Justice, Alexandria, Ma'arif Foundation, p. 14 ,

(9) Ali Bin Hadi and others, ( 1980)The New Dictionary for Students, ed. 2, Tunisia, Tunisian Distribution Company, p. 108.

(10) Abdullah Al-Bustani(1930) the Lebanese, Al-Bustan Fruits, Beirut, American Press, p. 1499,

(11) Dr. Khalil Al-Jar,(1973) Modern Arabic Lexicon, (Paris, El-Arous Library, p. 819

(12) Khaled Nasr Al-Sayed and Nevin Mohamed Tawfiq (2012), A Study on Transitional Justice, (Egypt, Parliamentary and Academic Studies and Research Unit, p. 9,

(13) Counselor Adel Majed ,2013) Transitional Justice and Successful Management of the Post-Revolution Period, Al Siyasa Al Dawliya, Issue 192, April, p. 14,

(14) Ahmed Shawki Banyoub(2013) Transitional Justice: Concept, Origins and Experiences, a working paper presented during a panel discussion held at the headquarters of the Center for Arab Unity Studies, Beirut, May 8, , p. 131

(15) Dr. Wahid Ferchichi and others,(2015) Handbook of Transitional Justice in Libya, Tunisia, Arab Institute for Human Rights, p. 79

(16) Dr. Salah Abdel-Rahman Al-Hadithi,( 2008)The Role of the United Nations in the Work of Truth and Reconciliation Commissions, Al-Huqooq Magazine, Issue( 4 ), p. 242.

(17) Basaer Ali Muhammad al-Bayati ,(2006), Rights of the victim before the International Criminal Court, $\mathrm{PhD}$ thesis in criminal law (unpublished), (Baghdad, College of Law, University of Baghdad, p. 278,.

(18) Miranda Saysons and Abdul Razzaq Al-Saadi,(2013) Legacy of Murr: Lessons from the De-Baathification Process in Iraq 2004-2012, (New York, International Center for Transitional Justice, p. 2

(19)Rahim Hassan Al-Aqili (2015) more exclusion and oppression in the Accountability and Justice Bill for the year, Iraq News Network, March 13, 2015 seen on 2/21/2019: www.alirqnews.com

(20) Imperfect Justice( 2017) Accountability for ISIS Crimes in Iraq .New York, Human Rights Watch, December p. 1

(21) Rahim Hassan Al-Aqili, more exclusion and oppression in the Accountability and Justice Bill for the year 2015, Iraq News Network, March 13, 2015 seen on 2/21/2019: www.alirqnews.com

(22) Imperfect Justice( 2017) Accountability for ISIS Crimes in Iraq .New York, Human Rights Watch, December p. 1 